\title{
COLONIAL NESTING BEHAVIOUR IN INDIAN POND HERON (ARDEOLA GRAYII GRAYII) OF BANGLADESH
}

\author{
Sajeda Begum
}

Department of Zoology, Jahangirnagar University, Savar, Dhaka, Bangladesh.

\begin{abstract}
A study was conducted on the nesting behaviour of Indian Pond Heron in Sitakunda, southeastern region of Bangladesh between January, 1995 and December, 1996. Indian Pond Heron is a solitary bird on its feeding grounds. It forms colonies when nesting. Eight species of plants were used for nest building in three colonies. Colonial nesting is an anti-predator adaptation in the Indian Pond Heron.
\end{abstract}

\section{Keywords}

Ardeola grayii grayii, Bangladesh, colonial nesting, Indian Pond Heron, nesting behaviour

\section{Introduction}

The Indian Pond Heron (Ardeola grayii grayii), commonly known as the 'paddy bird' is found in a wide range of wetland habitats, such as inundated paddy fields, marshy areas, and coastal areas and near all types of water bodies. The Indian Pond Heron is a solitary feeder and defends its feeding grounds. Breeding activities start with colonial roosting.

Colonial nesting behaviour is observed in a variety of bird families. They are believed to have evolved under several ecological pressures, including limitation of available nest sites, predation pressure and distribution of food (Lack, 1968; Brown \& Orians, 1970; Hoogland \& Sherman, 1976). Many species of herons breed socially. Jenni (1969) suggested that coloniality in herons is not an adaptation for exploiting food, but Krebs $(1974,1978)$ considers that coloniality in the Ciconiiformes is an adaptation concerned with food exploitation. Good evidence of bird colonies serving as information centres only concerns a few passerines (Brown, 1986). This theory is not yet really proven in wading birds (Bayer, 1982; Waltz, 1982; Marion, 1989). Data on exact knowledge of the pattern of resource exploitation by herons are lacking.
This paper provides circumstantial evidence that information exchange at the Indian Pond Heron colony is not essential as they defend feeding territories and rarely need to find alternative feeding sites.

\section{Study site}

The study was conducted in Sitakunda $\left(22^{\circ} 25^{\prime}-22^{\circ} 40^{\prime} \mathrm{N}\right.$ latitude \& $91^{\circ} 35^{\prime}-91^{\circ} 45^{\prime} \mathrm{E}$ longitude). It is situated $221 \mathrm{~km}$ south-east of Dhaka and $37 \mathrm{~km}$ north of Chittagong port city, Bangladesh. Sitakunda is bounded on the west by the Bay of Bengal and to the east by hilly terrain which consists of mixed tropical semievergreen and tropical deciduous forest. A patch of mangrove forest $\left(10 \mathrm{~km}^{2}\right)$ is found in the coastal area, which was planted by the forest department.

Sitakunda is an area of $383 \mathrm{~km}^{2}$, supporting several human settlements (villages). These villages are surrounded by several species of local trees, mainly Artocarpus heterophyllus, Mangifera indica, Syzygium cumini, and Albizzia procera, planted by the villagers. One-third of the area $\left(128 \mathrm{~km}^{2}\right)$ consists of paddy fields, which lie between the hill and the coast. These low-lying areas of Sitakunda become flooded from the end of May until the middle of September due to the heavy monsoon rainfall. Paddy is cultivated in these fields throughout the year, except in winter. Vegetables are cultivated during winter. There are several permanent and temporary (drying up in winter) ditches and marshy areas here. Several canals criss-cross the entire area. These canals become flooded during high tide and are shallow during low tide.

In general, the climate of Sitakunda is characterized by four pronounced seasons, the monsoon (June-September), postmonsoon (October-November), winter (December-February) and summer or pre-monsoon (March-May). Mean temperature is $30.1^{\circ} \mathrm{C} \pm 6.25^{\circ} \mathrm{C}$, the maximum temperature being $35.5^{\circ} \mathrm{C}$ in April and minimum $11.2^{\circ} \mathrm{C}$ in January. In 1995 the total rainfall in Sitakunda was recorded as 3201mm and 3752mm in 1996. 


\section{Materials and Methods}

Indian Pond Herons were observed in their natural habitat in Sitakunda. During the study period (January 1995 and December 1996), two days were spent in the second and fourth week of each month observing the Indian Pond Heron colonies at Sitakunda. The number of nests were counted and measured at the end of the breeding season. In some cases, nests which had been blown from the trees during heavy wind, were collected and measured. All trees in which nests were built were identified. The total number of trees and their height in each colony were recorded. The height of the nest was also recorded.

\section{Results and Discussion}

Three colonies were located at different sites in Sitakunda. All these colonies were near human habitation $(200-700 \mathrm{~m})$. The same sites were used for nest building in both 1995 and 1996 breeding seasons. Even old nests, which partly had been blown down due to poor construction during strong winds, were rebuilt at the same site. The number of nests in each colony varied from four to eight in each year (Fig. 1).

Only seven species of trees and one species of bamboo thickets were used to build nests in these colonies (Table 1). One colony

Table 1. Different species of trees used for nest building in nature

\begin{tabular}{|c|c|c|c|c|c|}
\hline Name of tree & NT & MDBH & $\begin{array}{r}\text { MCW } \\
(\mathrm{cm})\end{array}$ & $\begin{array}{l}\text { MTH } \\
\text { (m) }\end{array}$ & $\begin{array}{l}\mathrm{TN} \\
(\mathrm{m})\end{array}$ \\
\hline \multicolumn{6}{|l|}{ Anacardiaceae } \\
\hline Mangifera indica & 5 & 49.5 & 6.6 & 12.4 & 6 \\
\hline \multicolumn{6}{|l|}{ Moraceae } \\
\hline Artocarpus heterophyllus & 5 & 86.7 & 8.4 & 13.1 & 5 \\
\hline \multicolumn{6}{|l|}{ Myrtaceae } \\
\hline Syzygium cumini & 4 & 43.4 & 7.1 & 11.7 & 5 \\
\hline \multicolumn{6}{|l|}{ Leguminosae } \\
\hline Albizia procera & 3 & 61.3 & 11.1 & 18.3 & 3 \\
\hline \multicolumn{6}{|l|}{ Bombaceae } \\
\hline Bombax ceiba & 2 & 57.1 & 8.3 & 14.5 & 2 \\
\hline \multicolumn{6}{|l|}{ Papilionaceae } \\
\hline Erythrina indica & 2 & 47.2 & 5.3 & 8.5 & 2 \\
\hline Derris robusta & 3 & 77.5 & 12.0 & 15.0 & 1 \\
\hline \multicolumn{6}{|l|}{ Graminae } \\
\hline $\begin{array}{l}\text { Bambusa tulda } \\
\text { (Bamboo colony) }\end{array}$ & 21 & - & - & - & 15 \\
\hline
\end{tabular}

NT - Number of trees used for building nests; MDBH - mean DBH; MCW mean crown width (m); MTH - mean total height; TN - total number of nest

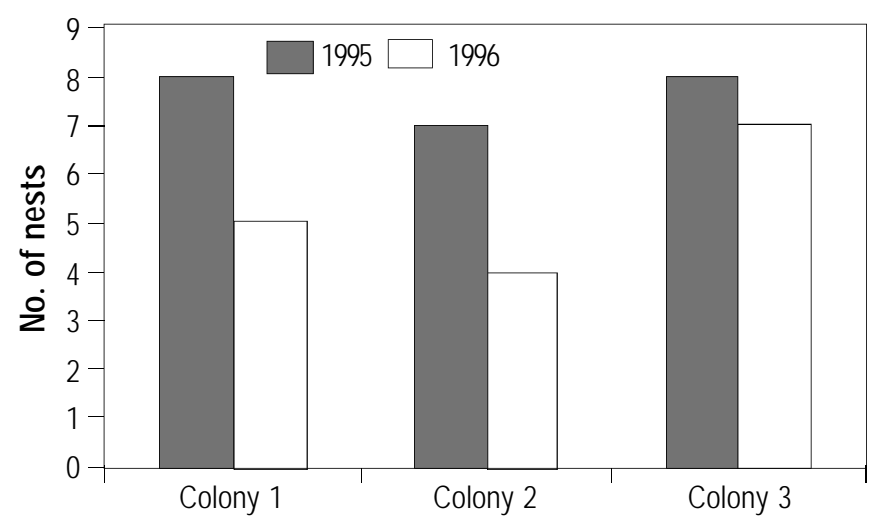

Figure 1. Number of nest in different colonies during the study period in Sitakunda.

was found in a bamboo thicket and all the nests $(n=15)$ were built on clumps of bamboo. In 1995, 14 trees of seven species were used for nest building in two colonies. In the next year, they used eight trees of only four species for nest building (Table 2). This is because, six trees had been cut down and others were trimmed by the local people which were used for nest building in the previous year. Characteristics of these nesting trees except the bamboo thickets are shown in Table 1.

In the bamboo colony, mean nesting heights were $10 \pm 1 \mathrm{~m}$, although the bamboo height ranged from 16 to $31 \mathrm{~m}$ (mean = $23.8 \pm 9.7, \mathrm{n}=21$ ). Nest height was more variable in the other two natural colonies (mean $=9.5 \pm 1.6$, range $=7-11 \mathrm{~m}, \mathrm{n}=22$ ), in trees ranging from 8 to $23 \mathrm{~m}$ in height $($ mean $=13.2 \pm 3.9, \mathrm{n}=22$ ). The height of the nest did not depend significantly on the height of the tree $(r=0.341, p=0.063, n=39)$. The nests were built more frequently between 9 and $10 \mathrm{~m}$ above the ground. This may be because the nests are constructed loosely and high nests in tall trees were always blown down during heavy winds. The frequency distribution of height of all nests is shown in Fig. 2.

Although the Indian Pond Heron is a solitary feeder, it forms colonies while nesting. A nesting colony acts as an information centre (Ward \& Zahavi, 1973), because the individuals do benefit in terms of a higher rate of food intake by joining other birds on the feeding grounds. Siegfried (1971) has proposed a similar explanation on the breeding colonies in another species of the family Ardeidae, the Cattle Egret (Bubulcus ibis), to show that the social structure of a species is closely related to feeding behaviour and food distribution. Several authors have discussed the significance of sociality in herons, and it has generally been concluded that colonial nesting in these species is not an adaptation for exploiting food resources (Lack, 1968; 
Table 2. Tree species used for nest building in different colony (except bamboo colony) by the pond heron during the study period

\begin{tabular}{|c|c|c|c|c|c|c|c|c|}
\hline \multirow[b]{2}{*}{ Year } & \multicolumn{4}{|c|}{ Colony 1} & \multicolumn{4}{|c|}{ Colony 2} \\
\hline & NTS & SN & NT & NN & NTS & SN & NT & NN \\
\hline \multirow[t]{6}{*}{1995} & & Mangifera indica & 2 & 3 & & Mangifera indica & 1 & 1 \\
\hline & & Artocarpus heterophyllus & 1 & 1 & & Artocarpus heterophyllus & 1 & 1 \\
\hline & 4 & Syzygium cumini & 2 & 2 & 6 & Syzygium cumini & 1 & 1 \\
\hline & & Erythrina indica & 2 & 2 & & Bombax ceiba & 2 & 2 \\
\hline & & & & & & Albizzia procera & 1 & 1 \\
\hline & & & & & & Derris robusta & 1 & 1 \\
\hline \multirow[t]{3}{*}{1996} & & Mangifera indica & 1 & 1 & & Mangifera indica & 1 & 1 \\
\hline & 3 & Artocarpus heterophyllus & 2 & 2 & 3 & Artocarpus heterophyllus & 1 & 1 \\
\hline & & Syzygium cumini & 1 & 2 & & Albizzia procera & 2 & 2 \\
\hline
\end{tabular}

NTS - Number of tree species; SN - scientific name; NT - number of trees; NN - number of nests

Jenni, 1969), since this could not account for the fact that herons often form mixed colonies with Cattle Egret, Little Egret (Egretta garzetta), Large Egret (Casmerodius albus) in which different species feed in different places, and also because some herons are social nesters and solitary feeders (Krebs, 1974). Colonial nesting in many species may primarily be an anti-predator device (Lack, 1968). Lack also pointed out that the food hypothesis cannot explain the formation of mixed colonies. In this study the breeding Indian Pond Herons in the colony chased away potential or actual predators i.e. Crested Serpent Eagle

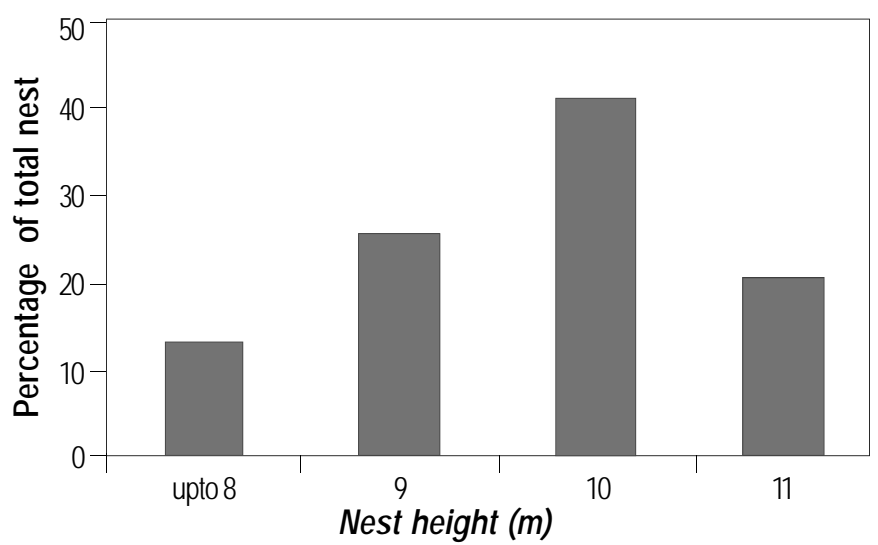

Figure 2. Frequency distribution of height of nests in Sitakunda $(n=39)$
(Spilornis cheela) and Brahminy Kite (Haliaster indus). When people tried to climb the tree, or if the birds felt any disturbance, alarm and threatening calls were given, but they did not leave the tree or colony. Thus, it seems that colonial nesting is an anti-predator adaptation in the Indian Pond Heron. It can also be visualised that shortage of safe nesting sites seems to force the herons to nest in colonies in Sitakunda, the study area. On the other hand, as a solitary feeder the Indian Pond Heron is not attracted to other feeding individuals on the feeding ground. Sometimes during winter, when all the feeding grounds dry out, Indian Pond Herons fed in loose parties, but it was not common. They were still defensive in loose parties and maintained distance between them. Information exchange at the colony of Indian Pond Heron does not seem to be very important, as this bird is a solitary feeder. Recently, it has also been noted that colonial nesting might be important as it favours the selection of suitable partners, by increasing the choice available in species which probably take new partners every year (Hoyo et al., 1992; van Vessem \& Draulance, 1986).

The foraging strategy of colonial herons varies between individuals and may change during the breeding season, depending upon the age and breeding performance of the birds involved, so it is difficult to justify the assumption of a generalised pattern for the colony (van Vessem et al., 1984). In order to explain why herons do not always nest alone when they are solitary feeders, one would have to postulate that they have a basic tendency towards colonial nesting (which evolved in conditions where social feeding was advantageous) and that the phenotypic modification of this tendency is only partial, perhaps because there is no disadvantage in colonial nesting 
(Krebs, 1974).

\section{Acknowledgements}

This research paper is a part of my M.Phil. Thesis prepared at the University of Cambridge, which was financially supported by the Cambridge Commonwealth Trust and ODA shared Scholarship. The fieldwork was conducted with financial support from the National Science and Technology (NST) fellowship programme of Bangladesh Government. I am grateful to the concerned authorities for their support. Dr. David J. Chivers, Department of Anatomy, University of Cambridge to whom I am indebted for making helpful comments and criticisms to clarify many of the ideas presented here supervised this study.

\section{References}

Bayer, R.D. (1982). How important are bird colonies as information centres? Auk 99: 31-40.

Brown, C.R. (1986). Cliff swallow colonies as information centres? Science 234: 83-85.

Brown, J.L. and G.H Orians (1970). Spacing patterns in mobile animals. Annual Review of Ecological Systems 1: 239-262.

Hoogland, J.L. and P.W. Sherman (1976). Advantages and disadvantages of bank swallow (Riparia riparia) coloniality. Ecological Monograph 46: 33-58.
Hoyo, D.J., A. Elliott and J. Sargatal (1992). Handbook of the Birds of the World. Vol.1. Lynx Edicions, Barcelona.

Jenni, D.A. (1969). A study of the ecology of four species of herons during the breeding season at Lake Alice Alachua County, Florida. Ecological Monograph 39: 245-270.

Krebs, J.R. (1974). Colonial nesting and social feeding as strategies for exploiting food resources in the Great Blue Heron (Ardea herodias). Behaviour 51: 99-134.

Krebs, J.R. (1978). Colonial nesting in birds, with special reference to the Ciconiiformes. Wading birds 299-314. National Audubon Society, New York.

Lack, D. (1968). Ecological Adaptations for Breeding in Birds. Methuen, London.

Marion, L. (1989). Territorial feeding and colonial breeding are not mutually exclusive- the case of the Grey Heron Ardea cinerea. Journal of Animal Ecology 58(2): 693-710.

Siegfried, W.R. (1971). Communal roosting of the cattle egret. Ardea 59: 38-46.

van Vessem, J., D. Draulans and A.F. de Bont (1984). Movements of radio-tagged grey heron Ardea cinerea during the breeding season in a large pond area. Ibis 126: 576-587.

van Vessem, J. and D. Draulans (1986). The adaptive significance of colonial breeding in the grey heron Ardea cinerea: inter and intracolonial variability in breeding success. Ornis Scand. 17: 356-362.

Ward, P. and A. Zahavi (1973). The importance of certain assemblages of birds as "information centers" for food-finding. Ibis 115: 517-534. Waltz, E.C. (1982). Resource characteristics and the evolution of information centres. American Naturalist 119: 73-90. 